\title{
Endiandrin A, a Potent Glucocorticoid Receptor Binder Isolated from the Australian Plant
}

\section{Endiandra anthropophagorum}

Rohan A. Davis, ${ }^{\dagger}$ Anthony R. Carroll, ${ }^{\dagger}$ Sandra Duffy, ${ }^{\dagger}$ Vicky M. Avery, ${ }^{\dagger}$ Gordon P. Guymer, ${ }^{\star}$ Paul

I. Forster, ${ }^{\star}$ and Ronald J. Quinn ${ }^{*} \dagger$

Eskitis Institute, Griffith University, Brisbane, QLD 4111, Australia, and Queensland Herbarium, Brisbane Botanic Gardens, Brisbane, QLD 4066, Australia.

\footnotetext{
${ }^{*}$ To whom correspondence should be addressed. Tel. +61-7-3735-6000. Fax: +61-7-3735-6001. E-mail: r.quinn@griffith.edu.au.

${ }^{\dagger}$ Eskitis Institute, Griffith University

* Queensland Herbarium
} 
Bioassay-guided fractionation of the DCM extract from the roots of Endiandra anthropophagorum resulted in the isolation of a new cyclobutane lignan endiandrin A (1), together with the known natural products, nectandrin B (2) and (-)-dihydroguaiaretic acid (3). The structure of 1 was determined by extensive 1D and 2D NMR, and MS data analyses. Acetylation and methylation of 1 yielded di-O-acetylendiandrin A (4) and di-O-methylendiandrin A (5), respectively. All compounds were tested in a glucocorticoid receptor binding assay and displayed $\mathrm{IC}_{50}$ values ranging from 0.9 to $35 \mu \mathrm{M}$. 
The glucocorticoid receptor (GR) is a ligand-activated intra-cytoplasmatic transcription factor that is a member of the nuclear hormone receptor superfamily. ${ }^{1,2}$ Glucocorticoids play an essential role in maintaining basal and stress-related homeostasis, and display potent antiinflammatory and immunosuppressive properties. ${ }^{1,2}$ As a consequence, synthetic glucocorticoids are widely used as drugs to treat inflammatory conditions such as rheumatoid arthritis or dermatitis, and as adjunction therapy for conditions such as autoimmune diseases. However, current glucocorticoid drugs act non-selectively, with the potential of long term impairment of many healthy anabolic processes. ${ }^{3}$ Therefore, research aimed at discovering selective novel GR binders may provide new and improved drug therapies.

During HTS of a library containing 72,079 crude biota extracts we discovered that the DCM extract from the roots of the rainforest tree Endiandra anthropophagorum (Lauraceae) showed potent activity in a GR binding assay. Bioassay-guided fractionation of the crude DCM extract resulted in the isolation of a new cyclobutane lignan, which we have named endiandrin A (1), along with the previously reported natural products, nectandrin B (2) and (-)-dihydroguaiaretic acid (3). Herein we report the isolation, structure elucidation and GR binding activity of endiandrin A (1).

\section{Results and Discussion}

The air-dried roots of E. anthropophagorum were extracted with DCM and the resulting lipophilic material was chromatographed using $\mathrm{C}_{18}$ bonded silica HPLC. Further purification using Sephadex LH-20 gel permeation chromatography followed by diol bonded silica HPLC yielded endiandrin A (1, $122 \mathrm{mg}, 0.735 \%$ dry wt), nectandrin B (2, $5.4 \mathrm{mg}, 0.033 \%$ dry wt) and (-)dihydroguaiaretic acid (3, $1.5 \mathrm{mg}, 0.009 \%$ dry wt).

Endiandrin A (1) was isolated as an optically active colorless oil and was assigned the molecular formula $\mathrm{C}_{20} \mathrm{H}_{24} \mathrm{O}_{4}$ on the basis of HRESIMS and NMR data. The small number of resonances in both the ${ }^{1} \mathrm{H}$ and ${ }^{13} \mathrm{C}$ NMR spectra (Table 1) coupled with the MS data indicated that 1 
was a symmetrical molecule containing nine degrees of unsaturation. The ${ }^{1} \mathrm{H}$ NMR spectrum of $\mathbf{1}$ displayed one exchangeable resonance $\left(\delta_{\mathrm{H}} 8.64\right)$, three aromatic resonances indicative of a trisubstituted benzene system $\left[\delta_{\mathrm{H}} 6.73(\mathrm{~d}, J=2.4 \mathrm{~Hz}), 6.67(\mathrm{~d}, J=8.4 \mathrm{~Hz})\right.$ and $6.61(\mathrm{dd}, J=8.4,2.4$ $\mathrm{Hz})]$, one methoxy group $\left(\delta_{\mathrm{H}} 3.72\right)$, two aliphatic resonances $\left(\delta_{\mathrm{H}} 2.70\right.$ and 1.71$)$ and a methyl resonance $\left(\delta_{\mathrm{H}} 1.12\right)$. The ${ }^{13} \mathrm{C}$ NMR spectrum of 1 contained only 10 resonances, six of which appeared between $\delta_{\mathrm{C}} 110$ and 148 suggesting the presence of an oxygenated phenyl ring. gHSQC analysis enabled all protons to be attached to their respective carbons. The trisubstituted phenyl rings were oxygenated since two carbons at $\delta_{\mathrm{C}} 147.4$ and $\delta_{\mathrm{C}} 144.8$ were observed in the ${ }^{13} \mathrm{C}$ NMR spectrum. The two methoxy groups were attached to C-3/C-3' since a strong HMBC correlation was identified from the methyl protons at $\delta_{\mathrm{H}} 3.72$ to the carbons at $\delta_{\mathrm{C}} 147.4$ and a strong ROESY correlation was observed between $\mathrm{H}-2 / \mathrm{H}-2$ ' and 3-OMe/3'-OMe. The two exchangeable protons at $\delta_{\mathrm{H}} 8.64$ were assigned to hydroxy groups substituted at C-4/C-4' since both protons showed HMBC correlations to C-3/C-3' and C-5/C-5' along with ROESY cross-peaks to H-5/H-5'. Analysis of the COSY data revealed that the methyl protons $\left(\delta_{\mathrm{H}} 1.12\right)$ were strongly coupled to the aliphatic protons at $\delta_{\mathrm{H}} 1.71$, which in turn shared a vicinal coupling to the remaining aliphatic protons at $\delta_{\mathrm{H}} 2.70$. These latter protons were determined to be benzylic since they showed HMBC correlations to the phenyl carbons C-1/C-1', C-2/C-2' and C-6/C-6'. COSY and ROESY correlations from $\delta_{\mathrm{H}} 2.70$ to both $\mathrm{H}-2 / \mathrm{H}-2$ ' and H-6/H-6' confirmed this arrangement. In order to satisfy the nine degrees of unsaturation, 1 needed to contain an additional ring. HMBC correlations from $\mathrm{H}-7$ to $\mathrm{C}-\mathrm{7}^{\prime}, \mathrm{H}-8$ to C-8', H-7' to C-7 and H-8' to C-8' indicated that the additional ring was a 1,2-dimethylcyclobutane system. Hence the planar structure for $\mathbf{1}$ was assigned. The assignment of the relative configuration for $\mathbf{1}$ initially proved difficult since numerous ROESY correlations were evident about the cyclobutane system and the ${ }^{1} \mathrm{H}-{ }^{1} \mathrm{H}$ coupling constants for $\mathrm{H}-7, \mathrm{H}-7$ ', $\mathrm{H}-8$ and $\mathrm{H}-8$ ' could not be determined. An unusual multiplet was observed for the benzylic protons, $\mathrm{H}-7$ and $\mathrm{H}-7^{\prime}$ at $\delta_{\mathrm{H}}$ 2.70. This unique multiplet had been previously reported for the related lignans, magnosalin (6), ${ }^{4-6}$ cinbalansan $(7)^{7}$ and heterotropan $(9) .{ }^{8}$ For 6 the H-7 and H-7' resonance pattern was labeled as a 
"diffused doublet", ${ }^{4}$ for 7 the authors referred to this multiplet as a "second-order doublet", 7 while for 9 "a virtual coupling was observed". ${ }^{8}$ The cinbalansan paper also recognized that both H-9 and H-9' appeared as second-order doublets. ${ }^{7}$ The ${ }^{1} \mathrm{H}$ NMR spectrum of 1 clearly contained these unique multiplets for $\mathrm{H}-7, \mathrm{H}-\mathrm{7}^{\prime}, \mathrm{H}-9$ and $\mathrm{H}-9^{\prime}$ and we refer to these as second-order doublets throughout this paper (see Figure 1). We report our measured doublet couplings in this paper however as Cuong et al. note, the magnitude of these values are most probably larger than the real values once second-order effects have been considered. ${ }^{7}$

In regards to the cyclobutane stereochemistry for this class of lignan, it should be noted that the relative configuration of magnosalin $(\mathbf{6})^{4}$ and its isomer andamanicin $(\mathbf{8})^{9}$ were initially misassigned. The correct stereostructures for $\mathbf{6}$ and $\mathbf{8}$ were determined following X-ray crystallographic studies on magnosalin. ${ }^{5}$

The spatial arrangement of the four substituents about the cyclobutane ring in $\mathbf{1}$ was determined to be symmetrical based on the NMR data. Six possible symmetrical isomers were possible for endiandrin A, however based on the optical rotation of $\mathbf{1}$ the two meso isomers were discounted. This left two pairs of enantiomers as the only possibilities for $\mathbf{1}$, and all four isomers contained the aryl moieties in a trans orientation. The orientation of the methyl substituents at C-8 and C-8' was determined by spectroscopic methods. Comparison of the ${ }^{1} \mathrm{H}$ NMR data in $\mathrm{CDCl}_{3}$ of 1 with $\mathbf{6}^{6}$ for $\mathrm{H}-8 / \mathrm{H}-8^{\prime}\left[\delta_{\mathrm{H}} 1.83(\mathbf{1}) ; \delta_{\mathrm{H}} 1.75(\mathbf{6})\right]$ and H-9/H-9' $\left[\delta_{\mathrm{H}} 1.20(\mathbf{1}) ; \delta_{\mathrm{H}} 1.19(\mathbf{6})\right]$ revealed only minor differences. In contrast, ${ }^{1} \mathrm{H}$ NMR data comparison of $\mathbf{1}$ with $\mathbf{7}^{7}$ and $\mathbf{9}^{6}$ showed a major chemical shift difference for H-8/H-8' [ $\left.\delta_{\mathrm{H}} 1.83(\mathbf{1}) ; \delta_{\mathrm{H}} 2.80(\mathbf{7}) ; \delta_{\mathrm{H}} 2.72(\mathbf{9})\right]$. These differences have been proposed to be due to the anisotropic effects of the aromatic rings attached to $\mathrm{C}-7$ and $\mathrm{C}$ $7^{\prime} .5$ Dreiding modelling studies ${ }^{5}$ performed on 6,8 and 9 had previously shown that $\mathrm{H}-8 / \mathrm{H}-8^{\prime}$ of 8 and 9 fell within the deshielding zone created by their aromatic rings while the same protons in $\mathbf{6}$ were orientated so that shielding effects were possible. ROESY correlations further supported the relative configuration of $\mathbf{1}$ being the same as $\mathbf{6}$ since strong cross-peaks were observed between H8/H-8' and the aryl protons $\mathrm{H}-2 / \mathrm{H}-2$ ' and $\mathrm{H}-6 / \mathrm{H}-6$ '. Based on these data we assigned the relative 
configuration of 1 as $8 \beta, 8^{\prime} \alpha$-dimethyl-7 $\alpha, 7^{\prime} \beta$-bis-(3-methoxy-4-hydroxyphenyl)cyclobutane. Acetylation and methylation of 1 afforded di-O-acetylendiandrin A (4) and di-O-methylendiandrin A (5), respectively, and both these compounds were spectroscopically characterized in a similar manner to 1 using 1D and 2D NMR, IR, UV and MS data. These synthetic analogs provided further confirmation of the two phenolic hydroxy groups present in $\mathbf{1}$. Compound $\mathbf{2}$ was determined to be nectandrin B following comparison of the NMR and $[\alpha]_{D}$ data with literature values. ${ }^{10,11}$ In a similar manner (-)-dihydroguaiaretic acid was assigned to compound $\mathbf{3}$ after spectroscopic data comparisons. $^{12-14}$

Compounds 1-5 were tested in a GR binding assay and displayed $\mathrm{IC}_{50}$ values of $0.9 \mu \mathrm{M}(\mathbf{1})$, $27 \mu \mathrm{M}$ (2), $35 \mu \mathrm{M}$ (3) and $34 \mu \mathrm{M}$ (4) and $13 \mu \mathrm{M}$ (5). The data for the natural products 1-3 suggests that the constrained four membered ring of $\mathbf{1}$, which has obvious implications on the spatial arrangements of the aryl and methyl substituents, is important for the potent GR activity. The GR binding results for the synthetic analogs 4 and 5 suggest that while one or both of the phenolic hydroxy groups in $\mathbf{1}$ does assist in the interaction of endiandrin A with the GR receptor they are not essential for GR activity. However, increasing the steric bulk of the C-4/C-4' substituents in the cyclobutane series was shown to significantly reduce the activity. Specifically, a 14.4- and 37.8fold decrease in activity was observed when the hydroxy groups of 1 were replaced with methoxy and acetoxy moieties in $\mathbf{5}$ and $\mathbf{4}$, respectively.

While over 2000 compounds belonging to the lignan structure class have been isolated, lignans containing a cyclobutane moiety are rare. ${ }^{15}$ Endiandrin A represents only the twenty-third naturally occurring cyclobutane lignan. ${ }^{15}$

\section{Experimental Section}

General Experimental Procedures. Optical rotations were recorded on a Jasco P-1020 polarimeter. UV and IR spectra were recorded on a Camspec M501 spectrophotometer and a Bruker Tensor 27 spectrometer, respectively. NMR spectra were recorded at $30{ }^{\circ} \mathrm{C}$ on either a 
Varian $500 \mathrm{MHz}$ or $600 \mathrm{MHz}$ Unity INOVA spectrometer. The latter spectrometer was equipped with a triple resonance cold probe. The ${ }^{1} \mathrm{H}$ and ${ }^{13} \mathrm{C}$ chemical shifts were referenced to the protodeutero solvent peaks for DMSO- $d_{6}$ at $\delta_{\mathrm{H}} 2.49$ and $\delta_{\mathrm{C}} 39.5$ or for $\mathrm{CDCl}_{3}$ at $\delta_{\mathrm{H}} 7.26$ and $\delta_{\mathrm{C}} 77.0$. LRESIMS were recorded on a Waters ZQ mass spectrometer. HRESIMS were recorded on a Bruker Daltonics Apex III 4.7e Fourier-transform mass spectrometer. Sephadex LH-20 packed into an open glass column $(50 \mathrm{~mm} \times 600 \mathrm{~mm})$ was used for gel permeation chromatography. A Waters 600 pump equipped with a Waters 996 PDA detector and a Waters 717 autosampler were used for HPLC. A ThermoElectron $\mathrm{C}_{18}$ Betasil $5 \mu \mathrm{m} 143 \AA$ column $(21.2 \mathrm{~mm} \times 150 \mathrm{~mm})$ and a YMC diol 5 $\mu \mathrm{m} 120 \AA$ column $(20 \mathrm{~mm} \times 150 \mathrm{~mm})$ were used for semi-preparative HPLC separations. All solvents used for chromatography, UV, optical rotations and MS were Lab-Scan HPLC grade, and the $\mathrm{H}_{2} \mathrm{O}$ was Millipore Milli-Q PF filtered. All synthetic reagents were purchased from SigmaAldrich.

Plant Material. The roots of E. anthropophagorum were collected at State Forest 143, Mt Lewis, Queensland, Australia during June of 1996. A voucher sample (AQ603481) has been lodged at the Queensland Herbarium, Brisbane, Australia.

Extraction and Isolation. The air-dried and ground roots of E. anthropophagorum (16.6 g) were exhaustively extracted with DCM (1 L). The solvent was evaporated to yield a dark brown residue $(1.27 \mathrm{~g})$ that was pre-absorbed to $\mathrm{C}_{18}(5 \mathrm{~g})$. The pre-absorbed material was packed into a stainless steel cartridge $(25 \times 50 \mathrm{~mm})$ and the cartridge attached to a $\mathrm{C}_{18}$ semi-preparative HPLC column. A linear gradient from $\mathrm{H}_{2} \mathrm{O}$ containing $1 \%$ TFA to $\mathrm{MeOH}$ containing $1 \%$ TFA at a flowrate of $9 \mathrm{~mL} / \mathrm{min}$ over $60 \mathrm{~min}$ was run and $1 \mathrm{~min}$ fractions were collected. Fractions 33 to 38 contained the bioactive material and were combined $(460 \mathrm{mg})$ and further purified using Sephadex LH-20 gel permeation chromatography with $100 \% \mathrm{MeOH}$ as the eluent at a flowrate of $5 \mathrm{~mL} / \mathrm{min}$. Fractions 44 to 48 contained all the activity and were combined $(217 \mathrm{mg})$ then pre-absorbed to diol bonded silica $(1 \mathrm{~g})$. This material was packed into a stainless steel cartridge $(10 \times 20 \mathrm{~mm})$ and then attached to a diol semi-preparative HPLC column. Isocratic conditions of $100 \% \mathrm{n}$-hexanes was 
maintained for the first $10 \mathrm{~min}$ at a flowrate of $9 \mathrm{~mL} / \mathrm{min}$, then a linear gradient to $20 \% \mathrm{i}$ $\mathrm{PrOH} / 80 \% \mathrm{n}$-hexanes was performed over $40 \mathrm{~min}$ at a flowrate of $9 \mathrm{~mL} / \mathrm{min}$. Isocratic conditions of $20 \% \mathrm{i}-\mathrm{PrOH} / 80 \% \mathrm{n}$-hexanes were maintained for a further $10 \mathrm{~min}$ at a flowrate of $9 \mathrm{~mL} / \mathrm{min}, 60$ fractions (1 min each) were collected. Fraction 35 contained pure (-)-dihydroguaiaretic acid (3, 1.5 $\mathrm{mg})$, fractions 36 to 38 were endiandrin A $(\mathbf{1}, 122 \mathrm{mg})$ and fraction 45 was nectandrin $\mathrm{B}(2,5.4$ $\mathrm{mg})$.

Endiandrin A (1): Colorless oil; $[\alpha]_{\mathrm{D}}^{22}-51\left(\right.$ c $\left.0.190, \mathrm{CHCl}_{3}\right) ; \mathrm{UV}(\mathrm{MeOH}) \lambda_{\max }(\log$ ع) 231 (3.99), $283 \mathrm{~nm}(3.63)$; IR $v_{\max }(\mathrm{NaCl}) 1515,1453,1267,1032 \mathrm{~cm}^{-1} ;{ }^{1} \mathrm{H}$ and ${ }^{13} \mathrm{C} \mathrm{NMR}$ data (DMSO-d $)_{6}$ see Table 1; ${ }^{1} \mathrm{H}$ NMR $\left(500 \mathrm{MHz}, \mathrm{CDCl}_{3}\right) \delta 1.20^{a}(6 \mathrm{H}, \mathrm{d}, J=6.0 \mathrm{~Hz}, \mathrm{H}-9, \mathrm{H}-$ 9'), 1.83 (2H, m, H-8, H-8'), 2.76 (2H, d, J=9.0 Hz, H-7, H-7'), 3.85 (6H, s, 3-OMe, 3'-OMe), $5.50\left(2 \mathrm{H}, \mathrm{brs}, 4-\mathrm{OH}, 4^{\prime}-\mathrm{OH}\right), 6.68\left(2 \mathrm{H}, \mathrm{d}, J=2.0 \mathrm{~Hz}, \mathrm{H}-2, \mathrm{H}-2^{\prime}\right), 6.73(2 \mathrm{H}, \mathrm{dd}, J=8.0,2.0 \mathrm{~Hz}$, H-6, H-6'), 6.85 (2H, d, J=8.0 Hz, H-5, H-5'); ${ }^{13} \mathrm{C}$ NMR (125 MHz, CDCl $) \delta 18.8$ (2C, C-9, C9'), 43.0 (2C, C-8, C-8'), 53.2 (2C, C-7, C-7'), 55.8 (2C, 3-OMe, 3'-OMe), 109.4 (2C, C-2, C-2'), 114.2 (2C, C-5, C-5'), 119.3 (2C, C-6, C-6'), 135.8 (2C, C-1, C-1'), 143.9 (2C, C-4, C-4'), 146.4 (2C, C-3, C-3'); (-)-LRESIMS m/z (rel. int.) 148 (25), 149 (10), 163 (30), 327 (10) [M-H]', 363 (100) $\left[\mathrm{M}+{ }^{35} \mathrm{Cl}\right]^{-}, 365(35)\left[\mathrm{M}+{ }^{37} \mathrm{Cl}\right]^{-}, 441(10)$; (+)-LRESIMS m/z (rel. int.) 145 (15), 165 (60), 173 (10), 205 (25), $351(100)[\mathrm{M}+\mathrm{Na}]^{+}$; (-)-HRESIMS m/z 327.1609 $\left(\mathrm{C}_{20} \mathrm{H}_{23} \mathrm{O}_{4}\right.$ [M-H] $^{-}$requires 327.1602). ${ }^{a}$ Second-order doublet.

Acetylation of Endiandrin A (1). Anhydrous pyridine $(0.5 \mathrm{~mL})$ and $\mathrm{Ac}_{2} \mathrm{O}(0.5 \mathrm{~mL})$ were added to endiandrin A (17.9 mg, $55 \mu \mathrm{mol})$ and the resulting mixture was stirred at $\mathrm{rt}$ for $24 \mathrm{~h}$. The solvents were evaporated to dryness, the remaining residue was pre-absorbed to diol bonded silica then packed into a stainless steel cartridge $(10 \times 20 \mathrm{~mm})$ and attached to a diol semi-preparative HPLC column. Isocratic conditions of $100 \%$ n-hexanes was maintained for the first 10 min, then a linear gradient to $20 \% \mathrm{i}-\mathrm{PrOH} / 80 \% \mathrm{n}$-hexanes was performed over $40 \mathrm{~min}$ at a flowrate of 9 $\mathrm{mL} / \mathrm{min}$. Isocratic conditions of $20 \% \mathrm{i}-\mathrm{PrOH} / 80 \% \mathrm{n}$-hexanes were maintained for a further $10 \mathrm{~min}$, 
60 fractions ( 1 min each) were collected. Fraction 26 contained pure di-O-acetylendiandrin A (4, $16.3 \mathrm{mg}, 71 \%$ yield).

Di-O-acetylendiandrin A (4): Colorless gum; $[\alpha]_{\mathrm{D}}^{22}-57\left(c 0.350, \mathrm{CHCl}_{3}\right) ; \mathrm{UV}$ $(\mathrm{MeOH}) \lambda_{\max }(\log \varepsilon) 225$ (4.22), $277 \mathrm{~nm}(3.73) ; \mathrm{IR} v_{\max }(\mathrm{NaCl}) 1764,1509,1368,1265,1197$, $1031 \mathrm{~cm}^{-1} ;{ }^{1} \mathrm{H}$ NMR (500 MHz, DMSO-d $) \delta 1.17^{a}(6 \mathrm{H}, \mathrm{d}, J=6.0 \mathrm{~Hz}, \mathrm{H}-9, \mathrm{H}-9$ ') 1.84 (2H, m, H-8, H-8'), 2.21 (6H, s, 4-OAc, 4'-OAc), 2.94 ${ }^{a}\left(2 \mathrm{H}, \mathrm{d}, J=9.0 \mathrm{~Hz}, \mathrm{H}-7, \mathrm{H}-7^{\prime}\right), 3.74$ (6H, s, 3OMe, 3'-OMe), 6.82 (2H, dd, J = 8.5, 1.5 Hz, H-6, H-6'), 6.95 (2H, d, J=1.5 Hz, H-2, H-2'), $6.96\left(2 \mathrm{H}, \mathrm{d}, J=8.5 \mathrm{~Hz}, \mathrm{H}-5, \mathrm{H}-5^{\prime}\right) ;{ }^{13} \mathrm{C}$ NMR $\left(125 \mathrm{MHz}, \mathrm{DMSO}-d_{6}\right) \delta 18.4\left(2 \mathrm{C}, \mathrm{C}-9, \mathrm{C}-9^{\prime}\right)$, 20.3 (2C, 4-OAc, 4'-OAc), 42.7 (2C, C-8, C-8'), 52.0 (2C, C-7, C-7'), 55.6 (2C, 3-OMe, 3'OMe), 111.1 (2C, C-2, C-2'), 118.6 (2C, C-6, C-6'), 122.5 (2C, C-5, C-5'), 137.6 (C-4, C-4'), 141.9 (2C, C-1, C-1'), 150.6 (2C, C-3, C-3'), 168.6 (2C, 4-OAc, 4'-OAc); (+)-LRESIMS m/z (rel. int.) 435 (100) $[\mathrm{M}+\mathrm{Na}]^{+}$; (+)-HRESIMS m/z $435.1773\left(\mathrm{C}_{24} \mathrm{H}_{28} \mathrm{O}_{6} \mathrm{Na}[\mathrm{M}+\mathrm{Na}]^{+}\right.$requires 435.1778). ${ }^{a}$ Second-order doublet.

Methylation of Endiandrin A (1). Endiandrin A (22.0 mg, $67 \mu \mathrm{mol})$ was dissolved in dry $\mathrm{MeOH}(1.5 \mathrm{~mL})$ and $\mathrm{Et}_{2} \mathrm{O}(1.5 \mathrm{~mL})$ then treated with excess $\mathrm{CH}_{2} \mathrm{~N}_{2}-\mathrm{Et}_{2} \mathrm{O}$ at $0{ }^{\circ} \mathrm{C}$ for $1 \mathrm{~h}$. The reaction was allowed to warm to rt overnight then the solvents were evaporated to afford pure di-Omethylendiandrin A (5, $23.0 \mathrm{mg}, 97 \%$ yield $)$.

Di-O-methylendiandrin A (5): White amorphous solid; $[\alpha]_{\mathrm{D}}{ }^{19}-62\left(c \mathrm{c} 0.123, \mathrm{CHCl}_{3}\right)$; $\mathrm{UV}(\mathrm{MeOH}) \lambda_{\max }(\log \varepsilon) 232$ (4.19), $281 \mathrm{~nm}$ (3.75); IR $v_{\max }(\mathrm{NaCl}) 1588,1515,1463,1415$ $1260,1239,1163,1140,1029,757 \mathrm{~cm}^{-1} ;{ }^{1} \mathrm{H}$ NMR (500 MHz, DMSO-d $) \delta 1.13^{a}(6 \mathrm{H}, \mathrm{d}, J=$ 6.0 Hz, H-9, H-9'), 1.75 (2H, m, H-8, H-8'), $2.77^{a}$ (2H, d, J = 9.0 Hz, H-7, H-7'), 3.69 (6H, s, 4OMe, 4'-OMe), 3.71 (6H, s, 3-OMe, 3'-OMe), 6.73 (2H, dd, J = 8.4, 1.8 Hz, H-6, H-6'), 6.77 $\left(2 \mathrm{H}, \mathrm{d}, J=1.8 \mathrm{~Hz}, \mathrm{H}-2, \mathrm{H}-2^{\prime}\right), 6.84\left(2 \mathrm{H}, \mathrm{d}, J=8.4 \mathrm{~Hz}, \mathrm{H}-5, \mathrm{H}-5{ }^{\prime}\right) ;{ }^{13} \mathrm{C} \mathrm{NMR}(125 \mathrm{MHz}$, DMSO-d $\left.{ }_{6}\right) \delta 18.4\left(2 \mathrm{C}, \mathrm{C}-9, \mathrm{C}-9^{\prime}\right), 42.6$ (2C, C-8, C-8'), 52.3 (2C, C-7, C-7'), 55.4 (2C, 3-OMe, 3'-OMe), 55.5 (2C, 4-OMe, 4'-OMe), 110.7 (2C, C-2, C-2'), 112.0 (2C, C-5, C-5'), 118.6 (2C, C- 
6, C-6'), 135.8 (2C, C-1, C-1'), 147.3 (C-4, C-4'), 148.7 (2C, C-3, C-3'); (+)-LRESIMS m/z (rel. int.) $151(15), 170(10), 179(10), 188(10), 219(10), 379(100)[\mathrm{M}+\mathrm{Na}]^{+}, 409(15)$; (+)HRESIMS m/z $379.1879\left(\mathrm{C}_{22} \mathrm{H}_{28} \mathrm{O}_{4} \mathrm{Na}[\mathrm{M}+\mathrm{Na}]^{+}\right.$requires 379.1879$) .{ }^{a}$ Second-order doublet.

Nectandrin B (2): Colorless oil (5.4 mg, 0.033\% dry wt); identified by comparison with literature data. ${ }^{10,11}$

(-)-Dihydroguaiaretic Acid (3): Colorless solid (1.5 mg, 0.009\% dry wt); identified by comparison with literature data. ${ }^{12-14}$

GR Binding Assay. A manufactured GR competitor assay kit was purchased from PANVERA (part \# PR2893D). This is a fluorescence polarization assay utilizing wavelengths within the red spectrum (535 nm excitation, $595 \mathrm{~nm}$ emission). The assay was converted to a 384 well format using small volume 384 well plates (Greiner bio-one cat \# 784076) to minimize reagent usage. The labelled ligand from this kit was used at a final concentration of $1 \mathrm{nM}$ and the receptor 4 $\mathrm{nM}$ in a total assay volume of $15 \mu \mathrm{L}$. The compound/extract was solubilized in $100 \%$ DMSO and 1 $\mu \mathrm{L}$ of this solution plus $4 \mu \mathrm{L}$ of $\mathrm{H}_{2} \mathrm{O}$ were aspirated into the 384 well plate. Five $\mu \mathrm{L}$ of both the labelled ligand and receptor were then added sequentially to the compound/extract assay plate (final DMSO concentration $=6.66 \%$ ). The assay plate was incubated at $\mathrm{rt}$ for $90 \mathrm{~min}$ then measured using a Victor II multi reader (PerkinElmer) (535 nm excitation, $595 \mathrm{~nm}$ emission).

Dexamethasone (Sigma cat \# D-1756) was used as a reference compound and gave an average $\mathrm{IC}_{50}$ of $2.74 \mathrm{nM}(\mathrm{SEM}+/-0.57 \mathrm{nM})$ when tested in quadruplicate over a period of several days. $\mathrm{IC}_{50}$ values for the isolated compounds were obtained by testing three wells per concentration within three individual assays.

Acknowledgment. The authors would like to acknowledge AstraZeneca for financial support. We thank Hoan The Vu from Griffith University for acquiring the HRESIMS measurements. 
Supporting Information Available: ${ }^{1} \mathrm{H}$ and ${ }^{13} \mathrm{C}$ NMR spectra and LRESIMS data for endiandrin A (1), di-O-acetylendiandrin A (4) and di-O-methylendiandrin A (5). This material is available free of charge via the Internet at http://pubs.acs.org.

\section{References and Notes}

(1) Pujols, L.; Mullol, J.; Torrego, A.; Picado, C. Allergy 2004, 59, 1042-1052.

(2) Bamberger, C. M.; Schulte, H. M.; Chrousos, G. P. Endocr. Rev. 1996, 17, 245-261.

(3) Tanaka, H.; Yoshikawa, N.; Shimizu, N.; Morimoto, C. Mod. Rheumatol. 2004, 14, 347355.

(4) Kikuchi, T.; Kadota, S.; Yanada, K.; Tanaka, K.; Watanabe, K.; Yoshizaki, M.; Yokoi, T.; Shingu, T. Chem. Pharm. Bull. 1983, 31, 1112-1114.

(5) Mahindru, R. N.; Taneja, S. C.; Dhar, K. L.; Brown, R. T. Phytochemistry 1993, 32, 10731075.

(6) Ryu, J.-H.; Son, H. J.; Lee, S. H.; Sohn, D. H. Bioorg. Med. Chem. Lett. 2002, 12, 649-651.

(7) Cuong, N. M.; Taylor, W. C.; Sung, T. V. Nat. Prod. Lett. 2001, 15, 331-338.

(8) Yamamura, S.; Niwa, M.; Nonoyama, M.; Terada, Y. Tetrahedron Lett. 1978, 4891-4894.

(9) Malhotra, S.; Koul, S. K.; Taneja, S. C.; Pushpangadan, P.; Dhar, K. L. Phytochemistry 1990, 29, 2733-2734.

(10) Le Quesne, P. W.; Larrahondo, J. E.; Raffauf, R. F. J. Nat. Prod. 1980, 43, 353-359.

(11) Shimomura, H.; Sashida, Y.; Oohara, M. Phytochemistry 1988, 27, 634-636.

(12) Carroll, A. R.; Taylor, W. C. Aust. J. Chem. 1990, 43, 1871-1879.

(13) Njoku, C. J.; Hopp, D. C.; Alali, F.; Asuzu, I. U.; McLaughlin, J. L. Planta Med. 1997, 63, $580-581$.

(14) Rao, K. V.; Chattopadhyay, S. K. J. Org. Chem. 1990, 55, 1427-1429.

(15) Dictionary of Natural Products on CD-ROM, version 15.2; Chapman and Hall Electronic Publishing Division: 2007. 


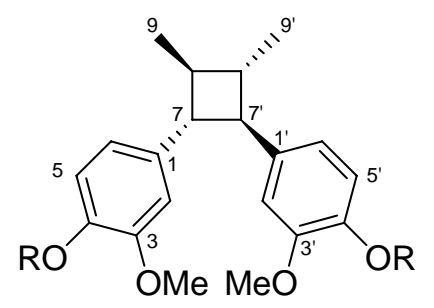

$\mathrm{R}=\mathrm{H} \quad$ Endiandrin A (1)

$\mathrm{R}=\mathrm{Ac} \quad$ Di-O-acetylendiandrin A (4)

$\mathrm{R}=\mathrm{Me}$ Di-O-methylendiandrin A (5)

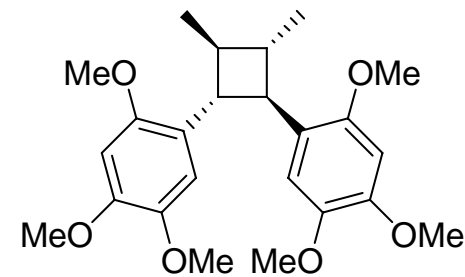

Magnosalin (6)<smiles>COc1cc([C@H]2O[C@@H](c3ccc(O)c(OC)c3)[C@H](C)[C@H]2C)ccc1O</smiles>

Nectandrin B (2)<smiles>COc1cc(C[C@H](C)[C@H](C)Cc2ccc(O)c(OC)c2)ccc1O</smiles>

(-)-Dihydroguaiaretic acid (3)<smiles>COc1cc(OC)c([C@H]2[C@@H](C)[C@@H](C)[C@H]2c2cc(OC)c(OC)cc2OC)cc1OC</smiles>

Andamanicin (8)<smiles>[R]c1cc(OC)c(OC)cc1[C@@H]1[C@H](C)[C@@H](C)[C@H]1c1cc(OC)c(OC)cc1[R]</smiles>

$\mathrm{R}=\mathrm{H} \quad$ Cinbalansan (7)

$\mathrm{R}=$ OMe Heterotropan (9) 

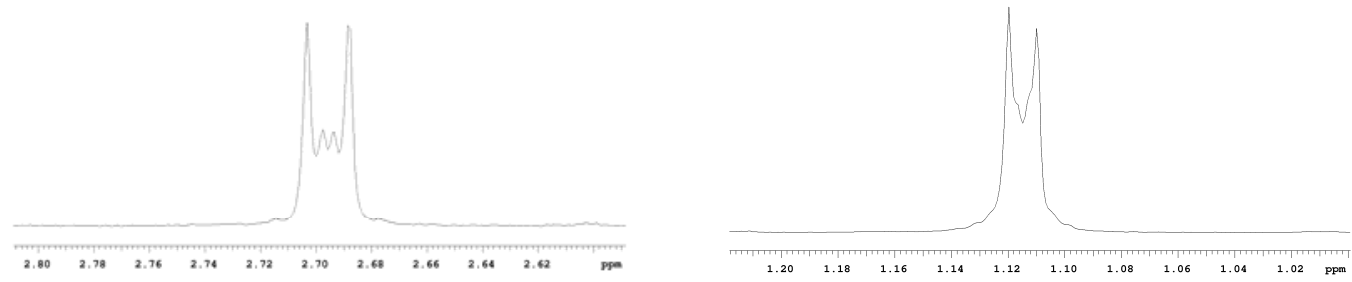

Figure 1. ${ }^{1} \mathrm{H}$ NMR spectrum expansions for H-7/H-7' $(\delta 2.70)$ and H-9/H-9' ( $\left.\delta 1.12\right)$ of 1 in DMSO- $d_{6}$ 
Table 1. NMR Data for Endiandrin A (1). ${ }^{a}$

\begin{tabular}{|c|c|c|c|c|c|}
\hline position & ${ }^{13} \mathrm{C}$ & ${ }^{1} \mathrm{H}$ (mult., $J$, int.) & gCOSY & gHMBC & ROESY \\
\hline 1 & 134.3 & & & & \\
\hline 2 & 111.0 & $6.73(\mathrm{~d}, 2.4,1 \mathrm{H})$ & 3-OMe, 6,7 & $1,3,4,6,7$ & 3-OMe, 7, 8, 9 \\
\hline 3 & 147.4 & & & & \\
\hline 3-OMe & 55.6 & $3.72(\mathrm{~s}, 3 \mathrm{H})$ & 2 & 2,3 & 2 \\
\hline 4 & 144.8 & & & & \\
\hline $4-\mathrm{OH}$ & & 8.64 (brs, $1 \mathrm{H})$ & & 3,5 & 5 \\
\hline 5 & 115.3 & $6.67(\mathrm{~d}, 8.4,1 \mathrm{H})$ & 6 & $1,3,4$ & 4-OH, 6 \\
\hline 6 & 118.9 & $6.61(\mathrm{~d}, 8.4,2.4,1 \mathrm{H})$ & $2,5,7$ & $2,4,7$ & $5,7,8$ \\
\hline 7 & 52.5 & $2.70(\mathrm{~d}, 9.0,1 \mathrm{H})^{b}$ & $2,6,8$ & $1,2,6,7^{\prime}, 8,9$ & $2,6,8,9^{\prime}$ \\
\hline 8 & 42.7 & $1.71(\mathrm{~m}, 1 \mathrm{H})$ & 7,9 & $1,7,8^{\prime}, 9^{\prime}, 9$ & $2,6,7^{\prime}, 9$ \\
\hline 9 & 18.5 & $1.12(\mathrm{~d}, 6.0,3 \mathrm{H})^{b}$ & 8 & $1,7,8,8^{\prime}, 9^{\prime}$ & $7,8,8^{\prime}$ \\
\hline $1^{\prime}$ & 134.3 & & & & \\
\hline $2^{\prime}$ & 111.0 & $6.73(\mathrm{~d}, 2.4,1 \mathrm{H})$ & 3'-OMe, 6', 7' & $1^{\prime}, 3^{\prime}, 4^{\prime}, 6^{\prime}, 7^{\prime}$ & 3'-OMe, 7', 8', 9' \\
\hline $3^{\prime}$ & 147.4 & & & & \\
\hline 3'-OMe & 55.6 & $3.72(\mathrm{~s}, 3 \mathrm{H})$ & $2^{\prime}$ & $2^{\prime}, 3^{\prime}$ & $2^{\prime}$ \\
\hline $4^{\prime}$ & 144.8 & & & & \\
\hline 4'-OH & & 8.64 (brs, $1 \mathrm{H})$ & & $3^{\prime}, 5^{\prime}$ & $5^{\prime}$ \\
\hline $5^{\prime}$ & 115.3 & $6.67(\mathrm{~d}, 8.4,1 \mathrm{H})$ & $6^{\prime}$ & $1^{\prime}, 3^{\prime}, 4^{\prime}$ & $4^{\prime}-\mathrm{OH}, 6^{\prime}$ \\
\hline $6^{\prime}$ & 118.9 & $6.61(\mathrm{dd}, 8.4,2.4,1 \mathrm{H})$ & $2^{\prime}, 5^{\prime}, 7^{\prime}$ & $2^{\prime}, 4^{\prime}, 7^{\prime}$ & $5^{\prime}, 7^{\prime}, 8^{\prime}$ \\
\hline $7^{\prime}$ & 52.5 & $2.70(\mathrm{~d}, 9.0,1 \mathrm{H})^{b}$ & $2^{\prime}, 6^{\prime}, 8^{\prime}$ & $1^{\prime}, 2^{\prime}, 6^{\prime}, 7,8^{\prime}, 9^{\prime}$ & $2^{\prime}, 6^{\prime}, 8^{\prime}, 9$ \\
\hline $8^{\prime}$ & 42.7 & $1.71(\mathrm{~m}, 1 \mathrm{H})$ & $7^{\prime}, 9^{\prime}$ & $1^{\prime}, 7^{\prime}, 8,9,9^{\prime}$ & $2^{\prime}, 6^{\prime}, 7,9^{\prime}$ \\
\hline $9^{\prime}$ & 18.5 & $1.12(\mathrm{~d}, 6.0,3 \mathrm{H})^{b}$ & $8^{\prime}$ & $1^{\prime}, 7^{\prime}, 8^{\prime}, 8,9$ & $7^{\prime}, 8^{\prime}, 8$ \\
\hline
\end{tabular}

${ }^{a}$ Spectra were recorded in DMSO- $d_{6}$ at $30{ }^{\circ} \mathrm{C}$. ${ }^{b}$ Second-order doublet. 
Endiandrin A, a Potent Glucocorticoid Receptor Binder Isolated from the Australian Plant Endiandra anthropophagorum

Rohan A. Davis, Anthony R. Carroll, Sandra Duffy, Vicky M. Avery, Gordon P. Guymer, Paul I. Forster, and Ronald J. Quinn

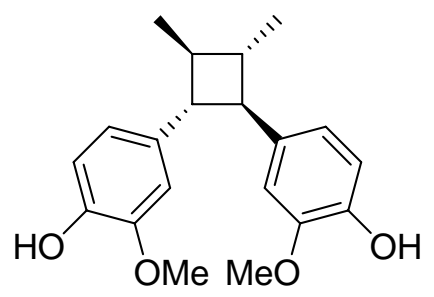

Endiandrin A 